\title{
Synthesis, Crystal Structure and Infrared Characterization of Bis(4-dimethylamino-pyridinium) Tetrachlorocuprate
}

\author{
Mahjouba Ben Nasr ${ }^{1}$, Frédéric Lefebvre ${ }^{2}$, Chérif Ben Nasr ${ }^{1}$ \\ ${ }^{1}$ Laboratoire de Chimie des Matériaux, Faculté des Sciences de Bizerte, Université de Carthage, Zarzouna, \\ Tunisie \\ ${ }^{2}$ Laboratoire de Chimie Organométallique de Surface (LCOMS), Ecole Supérieure de Chimie Physique \\ Electronique, Villeurbanne, France \\ Email: cherif bennasr@yahoo.fr
}

Received 16 March 2015; accepted 10 April 2015; published 13 April 2015

Copyright (C) 2015 by authors and Scientific Research Publishing Inc.

This work is licensed under the Creative Commons Attribution International License (CC BY). http://creativecommons.org/licenses/by/4.0/

\section{Abstract}

The chemical preparation, crystal structure and spectroscopic characterization of a novel organicinorganic hybrid material, bis(4-dimethylaminopyridinium) tetrachlorocuprate, have been reported. This compound crystallizes in the monoclinic system in space group $\mathrm{C} 2 / \mathrm{c}$ and cell parameters $\mathrm{a}=$ $12.4356(18), b=12.0901$ (17), $c=14.094$ (2) $\AA, \beta=115.303(2)^{\circ}, Z=4$ and $V=1915.8(5) \AA^{3}$. In the title salt, $\left(\mathrm{C}_{7} \mathrm{H}_{11} \mathrm{~N}_{2}\right)_{2} \mathrm{CuCl}_{4}$, both 4-dimethylaminopyridinium cations are protonated at their pyridine $\mathrm{N}$ atoms. The geometry of the $\mathrm{CuCl}_{4}^{2-}$ ions is intermediate between tetrahedral and square planar. The atomic arrangement can be described by an alternation of inorganic layers built up by tetrachlorocuprate anions and organic layers formed by 4-dimethylaminopyridinium cations. The organic layers are located in sandwich between the inorganic layers. The anionic and cationic layers are held together by $\mathrm{N}-\mathrm{H} \cdots \mathrm{Cl}$ and $\mathrm{C}-\mathrm{H} \cdots \mathrm{Cl}$ hydrogen bonds into a three-dimensional network. The individual cations are $\pi-\pi$ stacked with their neighbors at a distance of 3.7622 (5) $\AA$. The vibrational absorption bands were identified by infrared spectroscopy and DFT calculations allowed their attribution.

\section{Keywords}

Crystal Structure, 4-Dimethylaminopyridine, Hydrogen Bonds, $\pi-\pi$ Interactions, DFT Calculations 


\section{Introduction}

Non-covalent interactions, such as hydrogen bonding and $\pi-\pi$ stacking, play a very prominent role in the organization of structural units in both biochemistry and material science [1]-[3]. These weak interactions exercise important effects on the architecture and properties of many materials in various fields such as biology [4] [5] and crystal engineering [6] [7]. The control of these interactions will be important for the design of materials with specific types of properties such as conductivity or magnetic behavior [8]. Several works were focused on copper (II) halides to study the influence of the organic cation features on the packing interactions that govern the structural organization and consequently on the properties of this kind of complex [9] [10]. Recently, some studies have examined how metal halide oligomers can be tied together via pyridinium derivative cations into chains, layers, etc. [11]. It is well-know that organic-inorganic materials with pyridine and its derivatives as template agents have led to the preparation of some materials with interesting physical properties [12]-[16] and biological activities [17]-[19].

In connection with studies of the structural aspect of halo-metal anion salts containing pyridine derivatives [20]-[23], we herein report the crystal structure of $\left(\mathrm{C}_{7} \mathrm{H}_{11} \mathrm{~N}_{2}\right)_{2} \mathrm{CuCl}_{4}$ and its IR spectroscopic characterization.

\section{Experimental Procedure}

\subsection{Chemical Preparation}

$\mathrm{CuCl}_{2} \cdot 2 \mathrm{H}_{2} \mathrm{O}$ (1 mmol; $0.17 \mathrm{~g}$ ) was added to a 4-dimethylaminopyridine ( $\left.1 \mathrm{mmol} ; 0.12 \mathrm{~mL}\right)$ solution dissolved in $15 \mathrm{~mL}$ of absolute ethanol. The resulting solution was then acidified with $1 \mathrm{~mL}$ concentrated $\mathrm{HCl}$ and allowed to evaporate slowly at room temperature. Yellow block crystals were formed after 5 days (yield, 78.7\%).

\subsection{Investigation Techniques}

\subsubsection{X-Ray Single Crystal Structural Analysis}

Single crystals were carefully selected under a microscope and mounted on a Mitegen micromesh mount with the help of a trace of mineral oil. X-ray diffraction data were collected at $100 \mathrm{~K}$ on a Bruker Smart APEX CCD area-detector diffractometer using the $\omega$ scan technique with $\operatorname{MoK} \alpha$ radiation $(\lambda=0.7107 \AA)$. Data were collected, the unit cells determined, and the data integrated and corrected for absorption and other systematic errors using the Apex2 suite of programs [24]. SHELXS-97 [25] was used to solve the structures using direct methods and SHELTXL6.14 [26] and SHELXLE [27] were used for refinement. The packing diagrams were generated using the Mercury 2.3 package [28]. Crystal data and experimental parameters used for the intensity data collection are summarized in Table 1.

\subsubsection{Infrared Spectroscopy}

The IR spectrum was recorded in the range 4000 - $400 \mathrm{~cm}^{-1}$ with a "Perkin-Elmer FTIR-1000” spectrometer using samples dispersed in spectroscopically pure $\mathrm{KBr}$ pressed into a pellet.

\subsubsection{DFT Calculations}

The infrared spectrum was calculated with the Gaussian 09 software by assuming that in the $500-4000 \mathrm{~cm}^{-1}$ range all bands were due to the cation. The positions of the protons were optimized at the B3LYP/6-311++G** level of theory and the infrared spectrum was then calculated with the same method. No imaginary frequency was found showing the accuracy of these calculations. For plotting the spectrum a line broadening of $10 \mathrm{~cm}^{-1}$ was applied.

\section{Results and Discussion}

\subsection{Crystal Structure}

The structure of the title compound consists of discrete $\mathrm{CuCl}_{4}^{2-}$ anions and 4-dimethylaminopyridinium cations (Figure 1). Only the pyridinium $\mathrm{N}$ atom is protonated, while the amine group remains unprotonated, resulting in a charge of +1 for the organic cation. Thus, to ensure charge equilibrium, the structure associates each tetrachlorocuprate anion with two 4-dimethylaminopyridinium cations. The copper ion lies on a special position (Table 2) and it has a coordination geometry intermediate between tetrahedral and square planar with the trans- 

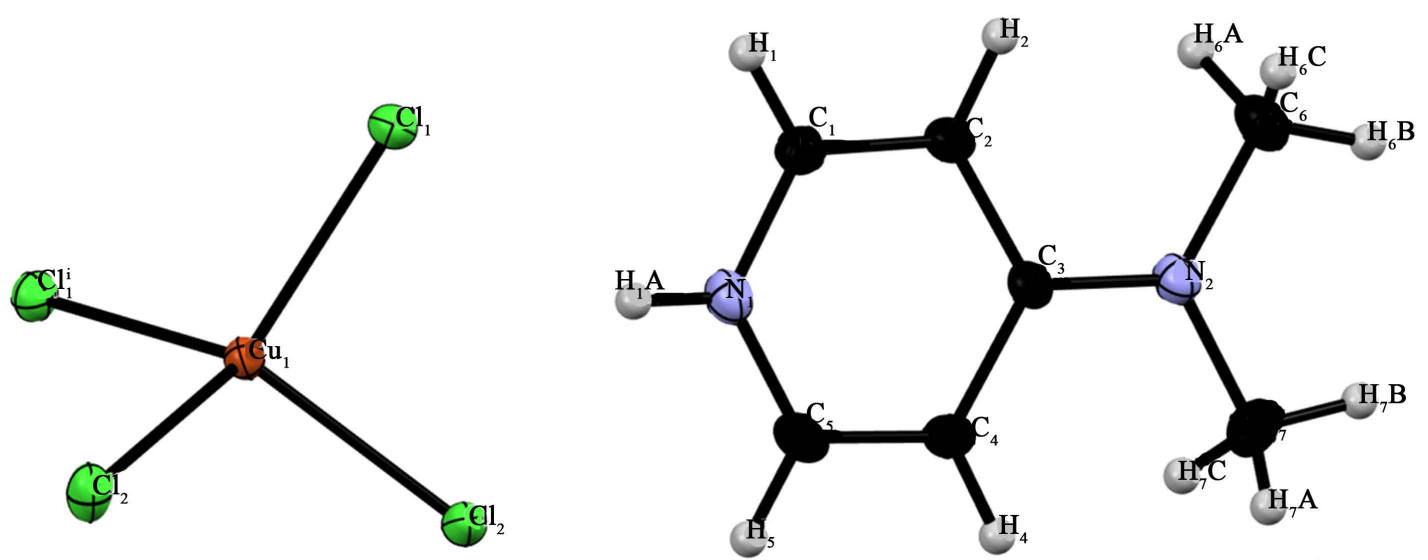

Figure 1. A view of the asymmetric unit in the crystal structure of $\left(\mathrm{C}_{7} \mathrm{H}_{11} \mathrm{~N}_{2}\right)_{2} \mathrm{CuCl}_{4}$ salt, showing the atomnumbering scheme and displacement ellipsoids drawn at the $50 \%$ probability level. Symmetry code: $\mathrm{i}=-\mathrm{x}+1, \mathrm{y}$, $-\mathrm{z}+1 / 2$.

Table 1. Experimental details of $\left(\mathrm{C}_{7} \mathrm{H}_{11} \mathrm{~N}_{2}\right)_{2} \mathrm{CuCl}_{4}$.

\begin{tabular}{|c|c|}
\hline \multicolumn{2}{|c|}{ Crystal data } \\
\hline Chemical formula & $2\left(\mathrm{C}_{7} \mathrm{H}_{11} \mathrm{~N}_{2}\right) \cdot \mathrm{Cl}_{4} \mathrm{Cu}$ \\
\hline$M_{\mathrm{r}}$ & 451.70 \\
\hline Crystal system, space group & Monoclinic, ${ }^{\circ} \mathrm{C} 2 / c$ \\
\hline Temperature (K) & 100 \\
\hline$a, b, c(\AA)$ & 12.4356 (18), 12.0901 (17), 14.094 (2) \\
\hline$\beta\left(^{\circ}\right)$ & $115.303(2)$ \\
\hline$V\left(\AA^{3}\right)$ & $1915.8(5)$ \\
\hline$Z$ & 4 \\
\hline Radiation type & $\mathrm{MoK \alpha}$ \\
\hline$\mu\left(\mathrm{mm}^{-1}\right)$ & 1.70 \\
\hline Crystal size (mm) & $0.55 \times 0.51 \times 0.45$ \\
\hline \multicolumn{2}{|c|}{ Data collection } \\
\hline Diffractometer & Bruker AXS SMART APEX CCD diffractometer \\
\hline Absorption correction & Multi-scan Apex2 v2011.2-0 (Bruker, 2011) \\
\hline$T_{\min }, T_{\max }$ & $0.541,0.746$ \\
\hline No. of measured, independent and observed $[I>2 \sigma(I)]$ reflections & 11188, 3100, 2920 \\
\hline$R_{\text {int }}$ & 0.016 \\
\hline$(\sin \theta / \lambda)_{\max }\left(\AA^{-1}\right)$ & 0.746 \\
\hline \multicolumn{2}{|l|}{ Refinement } \\
\hline$R\left[F^{2}>2 \sigma\left(F^{2}\right)\right], w R\left(F^{2}\right), S$ & $0.021,0.056,1.07$ \\
\hline No. of reflections & 3100 \\
\hline No. of parameters & 107 \\
\hline H-atom treatment & $\mathrm{H}$-atom parameters constrained \\
\hline$\Delta \rho_{\max }, \Delta \rho_{\min }\left(\mathrm{e} \cdot \AA^{-3}\right)$ & $0.50,-0.58$ \\
\hline
\end{tabular}


Table 2. Fractional atomic coordinates and isotropic or equivalent isotropic displacement parameters $\left(\AA^{2}\right)$ in $\left(\mathrm{C}_{7} \mathrm{H}_{11} \mathrm{~N}_{2}\right)_{2} \mathrm{CuCl}_{4}$.

\begin{tabular}{|c|c|c|c|c|}
\hline & $\mathrm{x}$ & $\mathrm{y}$ & $\mathrm{z}$ & $U_{\text {iso }}{ }^{*} / U_{\text {eq }}$ \\
\hline $\mathrm{C}_{1}$ & $0.17271(10)$ & $0.68038(9)$ & $0.35411(8)$ & 0.01752 (19) \\
\hline $\mathrm{H}_{1}$ & 0.1613 & 0.7278 & 0.2969 & $0.021^{*}$ \\
\hline $\mathrm{C}_{2}$ & $0.10691(9)$ & $0.69632(9)$ & $0.40965(8)$ & $0.01576(18)$ \\
\hline $\mathrm{H}_{2}$ & 0.0492 & 0.7537 & 0.3901 & $0.019^{*}$ \\
\hline $\mathrm{C}_{3}$ & $0.12487(9)$ & $0.62693(8)$ & $0.49683(8)$ & 0.01409 (17) \\
\hline $\mathrm{C}_{4}$ & $0.21230(10)$ & $0.54235(9)$ & $0.52141(9)$ & 0.01694 (19) \\
\hline $\mathrm{H}_{4}$ & 0.2281 & 0.4945 & 0.5793 & $0.020^{*}$ \\
\hline $\mathrm{C}_{5}$ & $0.27329(10)$ & $0.53025(9)$ & $0.46146(9)$ & $0.0194(2)$ \\
\hline $\mathrm{H}_{5}$ & 0.3307 & 0.4729 & 0.4777 & $0.023^{*}$ \\
\hline $\mathrm{C}_{6}$ & $-0.03134(10)$ & $0.72447(10)$ & $0.52349(9)$ & $0.0211(2)$ \\
\hline $\mathrm{H}_{6} \mathrm{~A}$ & 0.0041 & 0.7979 & 0.5284 & $0.032^{*}$ \\
\hline $\mathrm{H}_{6} \mathrm{~B}$ & -0.0701 & 0.7206 & 0.5710 & $0.032^{*}$ \\
\hline $\mathrm{H}_{6} \mathrm{C}$ & -0.0903 & 0.7115 & 0.4513 & $0.032^{*}$ \\
\hline $\mathrm{C}_{7}$ & $0.08652(11)$ & $0.57280(10)$ & $0.64620(9)$ & $0.0206(2)$ \\
\hline $\mathrm{H}_{7} \mathrm{~A}$ & 0.0762 & 0.4944 & 0.6266 & $0.031^{*}$ \\
\hline $\mathrm{H}_{7} \mathrm{~B}$ & 0.0315 & 0.5931 & 0.6765 & $0.031^{*}$ \\
\hline $\mathrm{H}_{7} \mathrm{C}$ & 0.1685 & 0.5858 & 0.6980 & $0.031^{*}$ \\
\hline $\mathrm{N}_{1}$ & $0.25385(8)$ & $0.59811(8)$ & $0.37942(7)$ & $0.01860(18)$ \\
\hline $\mathrm{H}_{1} \mathrm{~A}$ & 0.2945 & 0.5886 & 0.3421 & $0.022^{*}$ \\
\hline $\mathrm{N}_{2}$ & $0.06171(8)$ & $0.64013(8)$ & $0.55294(7)$ & $0.01696(17)$ \\
\hline $\mathrm{Cl}_{1}$ & $0.34860(2)$ & $0.68118(2)$ & 0.207499 (19) & $0.01598(6)$ \\
\hline $\mathrm{Cl}_{2}$ & $0.42347(2)$ & $0.43620(2)$ & $0.32353(2)$ & $0.01864(6)$ \\
\hline $\mathrm{Cu}_{1}$ & 0.5000 & 0.559866 (14) & 0.2500 & $0.01307(5)$ \\
\hline
\end{tabular}

bond angles of $141.19(1)^{\circ}$ for both $\mathrm{Cl}_{2}-\mathrm{Cu}_{1}-\mathrm{Cl}_{1}^{\mathrm{i}}$ and $\mathrm{Cl}_{2}^{\mathrm{i}}-\mathrm{Cu}_{1}-\mathrm{Cl}_{1}(\mathrm{i}=-\mathrm{x}+1, \mathrm{y},-\mathrm{z}+1 / 2)$ (Table 3). The $\mathrm{Cu}-\mathrm{Cl}$ bond distances are 2.2491(3) and 2.2562 (4) $\AA$. These bond distances and angles of $\mathrm{CuCl}_{4}^{2-}$ anion are in agreement with those found in other compounds [29].

Examination of the crystal structure of the title salt (Figure 2) reveals that the atomic arrangement can be described by inorganic layers parallel to $(\mathrm{a}, \mathrm{b})$ plane of $\mathrm{CuCl}_{4}^{2-}$ anions alternated with layers of 4-dimethylaminopyridinium cations. The organic layers are arranged in sandwich between the inorganic ones. Figure 3 shows that the inorganic layers are located at $z=(2 n+1) / 4$, while the organic ones are situated at $z=n / 2$. No significant inter-stack $\mathrm{Cl} \cdots \mathrm{Cl}$ interactions was observed (the shortest $\mathrm{Cl} \cdots \mathrm{Cl}$ contact is 4.459 (1) $\AA$ ).

Anions and cations are linked by a network of $\mathrm{N}-\mathrm{H} \cdots \mathrm{Cl}$ and $\mathrm{C}-\mathrm{H} \cdots \mathrm{Cl}$ hydrogen bonds into a three dimensional network. Among these hydrogen bonds, one is bifurcated $\mathrm{N}_{1}-\mathrm{H}_{1} A \cdots\left(\mathrm{Cl}_{1}, \mathrm{Cl}_{2}\right)$ (Table 4).

The geometric features of the organic cations are given in Table 3 . The values of the bond lengths and angles are similar to those observed in bis(4-dimethylaminopyridinium) tetrachlorozincate [30]. The sum of the angles around the $\mathrm{N}(2)$ nitrogen atom is close to $360^{\circ}$. The $\mathrm{C}_{3}-\mathrm{N}_{2}$ bond distance of the $\mathrm{NH}_{2}$ group is 1.341 (1) $\AA$, which is short for a C-N single bond, but still not quite as contracted as one would expect for a fully established $\mathrm{C}=\mathrm{N}$ double bond. This C-N bond length distance value is consistent with an imino resonance form as it is commonly found for a C-N single bond involving $\mathrm{sp}^{2}$ hybridized $\mathrm{C}$ and $\mathrm{N}$ atoms [31]. The shortening of the C- $\mathrm{N}_{\text {amino }}$ bond distance is probably due to the delocalization of the ring $\pi$ density with the p-orbital electrons of the 


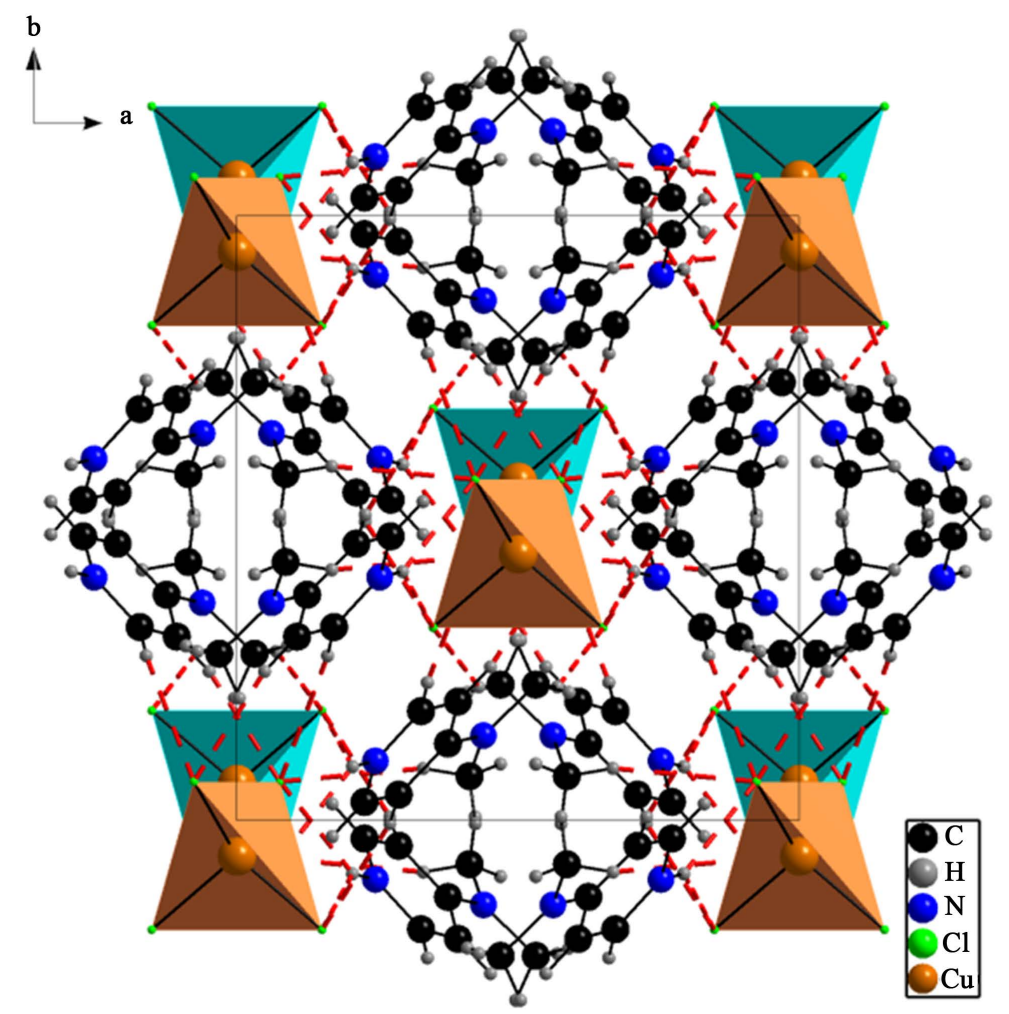

Figure 2. View of $\left(\mathrm{C}_{7} \mathrm{H}_{11} \mathrm{~N}_{2}\right)_{2} \mathrm{CuCl}_{4}$ along the $c$-axis. The dotted lines indicate hydrogen bonds.

Table 3. Selected bond distances and angles $\left(\AA,{ }^{\circ}\right)$ in $\left(\mathrm{C}_{7} \mathrm{H}_{11} \mathrm{~N}_{2}\right)_{2} \mathrm{CuCl}_{4}$.

$\begin{array}{cccc}\mathrm{C}_{1}-\mathrm{N}_{1} & 1.3517(14) & \mathrm{C}_{1}-\mathrm{C}_{2} & 1.3663(15) \\ \mathrm{C}_{2}-\mathrm{C}_{3} & 1.4244(14) & \mathrm{C}_{7}-\mathrm{N}_{2} & 1.4625(14) \\ \mathrm{C}_{3}-\mathrm{N}_{2} & 1.3412(13) & \mathrm{C}_{3}-\mathrm{C}_{4} & 1.4233(14) \\ \mathrm{C}_{4}-\mathrm{C}_{5} & 1.3632(15) & \mathrm{Cl}_{1}-\mathrm{Cu}_{1} & 2.2562(4) \\ \mathrm{C}_{5}-\mathrm{N}_{1} & 1.3526(15) & \mathrm{Cl}_{2}-\mathrm{Cu}_{1} & 2.2491(3) \\ \mathrm{C}_{6}-\mathrm{N}_{2} & 1.4631(14) & \mathrm{Cu}_{1}-\mathrm{Cl}_{2}{ }^{\mathrm{i}} & 2.2491(3) \\ \mathrm{C}_{6}-\mathrm{N}_{2} & 1.4631(14) & \mathrm{Cu}_{1}-\mathrm{Cl}_{1}{ }^{\mathrm{i}} & 2.2562(4) \\ \mathrm{N}_{1}-\mathrm{C}_{1}-\mathrm{C}_{2} & 120.99(10) & \mathrm{C}_{1}-\mathrm{N}_{1}-\mathrm{C}_{5} & 120.83(10) \\ \mathrm{C}_{1}-\mathrm{C}_{2}-\mathrm{C}_{3} & 119.98(9) & \mathrm{N}_{1}-\mathrm{C}_{5}-\mathrm{C}_{4} & 121.42(10) \\ \mathrm{N}_{2}-\mathrm{C}_{3}-\mathrm{C}_{4} & 121.39(10) & \mathrm{C}_{3}-\mathrm{N}_{2}-\mathrm{C}_{7} & 120.80(9) \\ \mathrm{N}_{2}-\mathrm{C}_{3}-\mathrm{C}_{2} & 121.55(9) & \mathrm{C}_{3}-\mathrm{N}_{2}-\mathrm{C}_{6} & 120.47(9) \\ \mathrm{C}_{4}-\mathrm{C}_{3}-\mathrm{C}_{2} & 117.06(9) & \mathrm{C}_{7}-\mathrm{N}_{2}-\mathrm{C}_{6} & 118.71(9) \\ \mathrm{C}_{5}-\mathrm{C}_{4}-\mathrm{C}_{3} & 119.71(10) & & \\ \mathrm{Cl}_{2}{ }^{\mathrm{i}}-\mathrm{Cu}_{1}-\mathrm{Cl}_{2} & 96.668(18) & \mathrm{Cl}_{2}{ }^{\mathrm{i}}-\mathrm{Cu}_{1}-\mathrm{Cl}_{1} & 141.190(11) \\ \mathrm{Cl}_{2}{ }^{\mathrm{i}}-\mathrm{Cu}_{1}-\mathrm{Cl}_{1}{ }^{\mathrm{i}} & 94.882(13) & \mathrm{Cl}_{2}-\mathrm{Cu}_{1}-\mathrm{Cl}_{1} & 94.879(13) \\ \mathrm{Cl}_{2}-\mathrm{Cu}_{1}-\mathrm{Cl}_{1}{ }^{\mathrm{i}} & 141.189(11) & \mathrm{Cl}_{1}{ }^{\mathrm{i}}-\mathrm{Cu}_{1}-\mathrm{Cl}_{1} & 98.908(18)\end{array}$

Symmetry code: (i) $-\mathrm{x}+1, \mathrm{y},-\mathrm{z}+1 / 2$. 


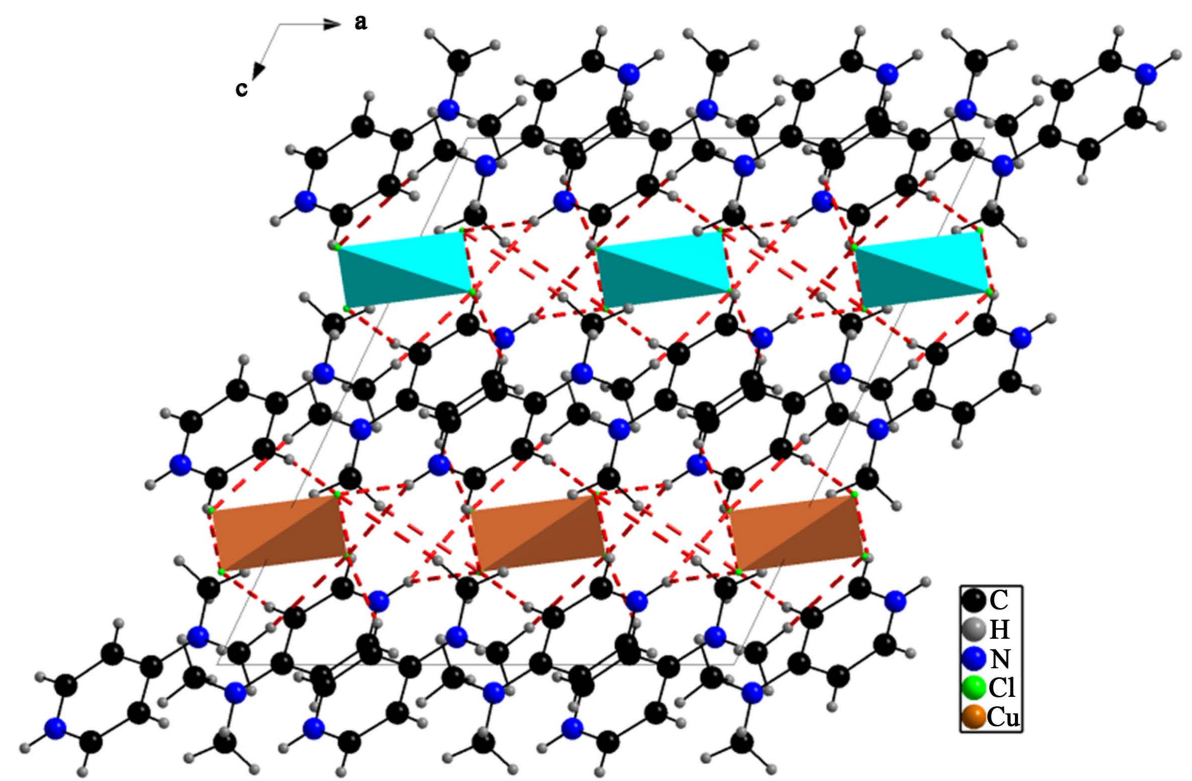

Figure 3. View of $\left(\mathrm{C}_{7} \mathrm{H}_{11} \mathrm{~N}_{2}\right)_{2} \mathrm{CuCl}_{4}$ along the $c$-axis. The dotted lines indicate hydrogen bonds.

Table 4. Hydrogen-bond geometry $\left(\AA,{ }^{\circ}\right)$ in $\left(\mathrm{C}_{7} \mathrm{H}_{11} \mathrm{~N}_{2}\right)_{2} \mathrm{CuCl}_{4}$.

\begin{tabular}{ccccc}
\hline$D-H \cdots A$ & $D-\mathrm{H}$ & $\mathrm{H} \cdots A$ & $D \cdots A$ & \multicolumn{2}{c}{$D-\mathrm{H} \cdots A$} \\
\hline $\mathrm{N}_{1}-\mathrm{H}_{1} A \cdots \mathrm{Cl}_{1}$ & 0.88 & 2.53 & $3.2726(10)$ & 143 \\
$\mathrm{~N}_{1}-\mathrm{H}_{1} A \cdots \mathrm{Cl}_{2}$ & 0.88 & 2.53 & $3.2128(12)$ & 135 \\
$\mathrm{C}_{2}-\mathrm{H}_{2} \cdots \mathrm{Cl}_{2}{ }^{\text {ii }}$ & 0.95 & 2.63 & $3.5667(13)$ & 167 \\
$\mathrm{C}_{4}-\mathrm{H}_{4} \cdots \mathrm{Cl}_{1}{ }^{\text {iii }}$ & 0.95 & 2.78 & $3.6408(13)$ & 152 \\
$\mathrm{C}_{6}-\mathrm{H}_{6} B \cdots \mathrm{Cl}_{1}{ }^{\text {iv }}$ & 0.98 & 2.79 & $3.6832(14)$ & 152 \\
$\mathrm{C}_{7}-\mathrm{H}_{7} C \cdots \mathrm{Cl}_{2}{ }^{\text {iii }}$ & 0.98 & 2.90 & $3.8554(15)$ & 163 \\
$\mathrm{C}_{1}-\mathrm{H}_{1} \cdots \mathrm{Cl}_{2}{ }^{\mathrm{v}}$ & 0.95 & 2.97 & $3.8347(12)$ & 152
\end{tabular}

Symmetry codes: (ii) $\mathrm{x}-1 / 2, \mathrm{y}+1 / 2$, $\mathrm{z}$; (iii) $\mathrm{x},-\mathrm{y}+1$, $\mathrm{z}+1 / 2$; (iv) $\mathrm{x}-1 / 2,-\mathrm{y}+3 / 2, \mathrm{z}+1 / 2$; (v) $-\mathrm{x}+1 / 2, \mathrm{y}+1 / 2,-\mathrm{z}+1 / 2$.

amino group. Consequently, the basicity of the $\mathrm{N}_{2}$ nitrogen atom decreases, which is in favor of the protonation of the $\mathrm{N}_{1}$ nitrogen atom of the pyridinic ring. Moreover, the C-N-C angles of the pyridine are very sensitive to protonation [32] [33]. A pyridinium cation always possesses an expanded C-N-C angle in comparison with the parent pyridine. The angle $\mathrm{C}_{1}-\mathrm{N}_{1}-\mathrm{C}_{5}$ of $120.83(10)^{\circ}$ is typical for the protonated forms of dimethylpyridine reported in many structures [34]-[52].

As it can be seen clearly from Figure 4 and Table 5, the two neighboring anti-parallel organic cations, which are not connected by hydrogen bonding, are stacked each other by turns in a face to face mode. The centroidcentroid distance is 3.7622 (5) $\AA$, less than $3.8 \AA$, the maximum value accepted for $\pi$ - $\pi$ interactions [53].

\subsection{IR Spectroscopy}

FTIR spectroscopy was used to identify the functional groups present in the crystal. The infrared absorption spectrum of $\left(\mathrm{C}_{7} \mathrm{H}_{11} \mathrm{~N}_{2}\right)_{2} \mathrm{CuCl}_{4}$ is shown in Figure 5. A detailed assignment of all bands observed in the infrared spectrum of the 4-dimethylaminopyridinium cation in the title compound is based on the comparison with other compounds associated to the same cation [54] [55]. In the domain of high frequencies, the bands at 3447, 3195, 3112, $2964 \mathrm{~cm}^{-1}$ are due to the stretching vibration frequencies of the N-H and C-H bonds. The band at 1644 $\mathrm{cm}^{-1}$ is assigned to the N-H bending mode. The bands at 1571 and $1452 \mathrm{~cm}^{-1}$ are attributed to the $\mathrm{C}=\mathrm{C}$ and $\mathrm{C}=\mathrm{N}$ stretching modes of the pyridine ring. The absorption band located at $1217 \mathrm{~cm}^{-1}$ corresponds to the $v(\mathrm{C}-\mathrm{N})$ and 


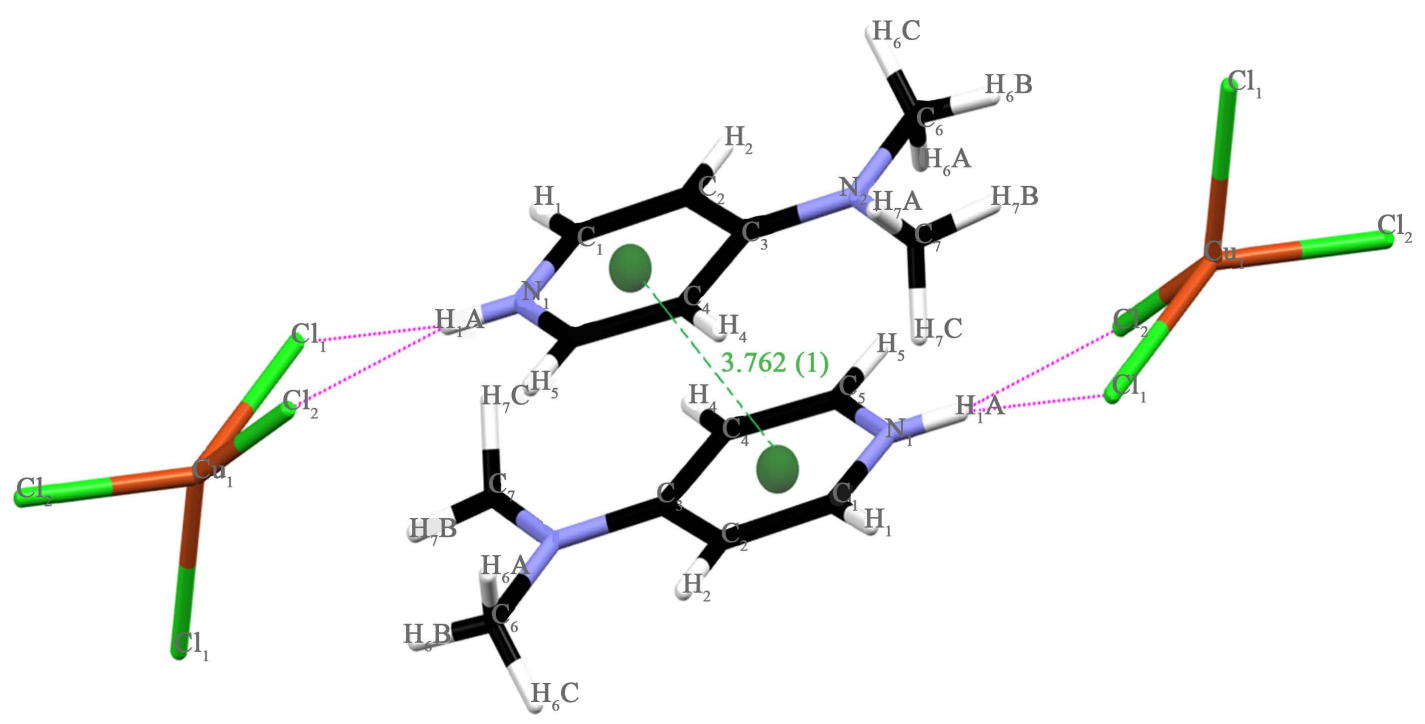

Figure 4. $\pi$ - $\pi$ stacking interactions between neighboring organic cations in the title compound.

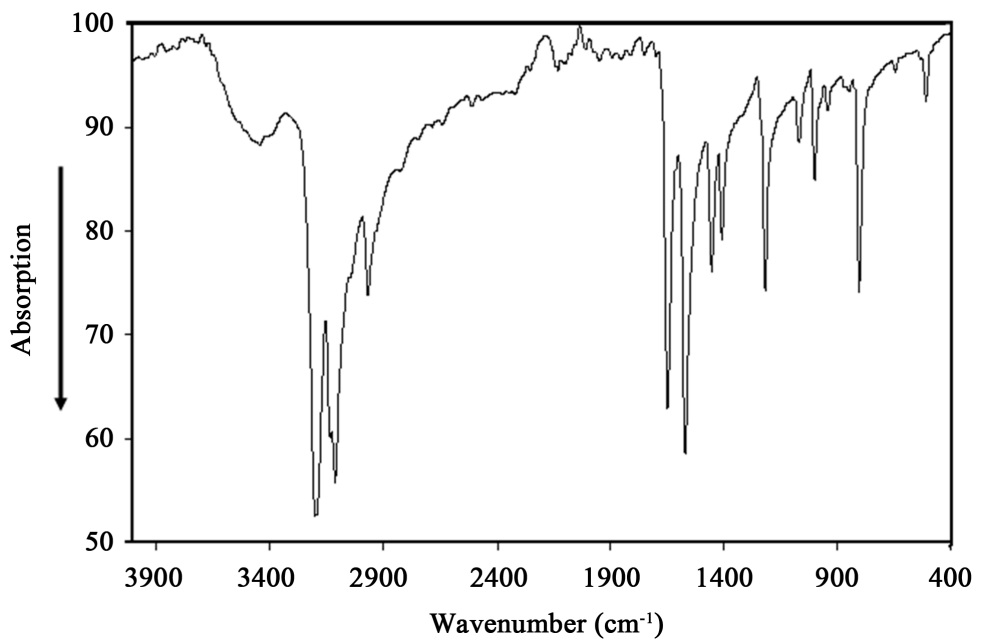

Figure 5. Infrared absorption spectrum of $\left(\mathrm{C}_{7} \mathrm{H}_{11} \mathrm{~N}_{2}\right)_{2} \mathrm{CuCl}_{4}$ salt.

Table 5. Geometry of $\pi \ldots \pi$ stacking interactions $\left(\AA,^{\circ}\right)$ in the title $\left(\mathrm{C}_{7} \mathrm{H}_{11} \mathrm{~N}_{2}\right)_{2} \mathrm{CuCl}_{4}$.

\begin{tabular}{cccccc}
\hline Group1/Group2 & $\mathrm{d}(\mathrm{CgI} \ldots \mathrm{CgJ})$ & $\alpha\left({ }^{\circ}\right)$ & $\beta\left({ }^{\circ}\right)$ & $\gamma\left({ }^{\circ}\right)$ & Dist_perp \\
\hline $\mathrm{Cg} 1 / \mathrm{Cg} 1^{\mathrm{i}}$ & $3.7622(5)$ & 0 & 25 & 25 & 3.4090 \\
\hline
\end{tabular}

Symmetry codes: (i) $1 / 2-x, 1 / 2-y,-z$. Cg1 is the centroid of $N_{1}-C_{5}$ ring. $d(C g I . . C g J)$ is the distance between the centroids of rings. $\alpha$ is the dihedral angle between planes I and J. $\beta$ is the angle between the vector $\mathrm{CgI} \rightarrow \mathrm{CgJ}$ and the normal to plane I. $\gamma$ is the angle between the vector $\mathrm{CgI} \rightarrow \mathrm{CgJ}$ and the normal to plane J. Dist_perp is the interplanar distance between the parallel rings I and J.

$v(\mathrm{C}-\mathrm{C})$ modes. The band at $1070 \mathrm{~cm}^{-1}$ can be attributed to the $\delta(\mathrm{C}-\mathrm{C})$ mode. The remaining bands in the range 1000 to $500 \mathrm{~cm}^{-1}$ are assigned to $\gamma(\mathrm{C}-\mathrm{C}), \gamma(\mathrm{C}-\mathrm{H})$ and $\gamma(\mathrm{C}-\mathrm{N})$ out-of-plane bending modes.

DFT calculations showed that the inorganic entities lead to vibrations below $500 \mathrm{~cm}^{-1}$ which are not observed experimentally in our conditions. So we focused only on the vibrations of the organic cation. X-ray diffraction data give $\mathrm{C}-\mathrm{H}$ or $\mathrm{N}-\mathrm{H}$ distances which are too small compared to what is usually observed (typically below 0.1 $\mathrm{nm}$ ) due to the fact that this method is not sensitive to the nuclei but to the electrons and so gives values corresponding to distances between the barycenters of electronic charges. As a consequence, the positions of protons were first optimized, the $\mathrm{C}$ and $\mathrm{N}$ atoms being located at the positions given by the $\mathrm{X}$-ray study. The resulting 
C-H and N-H distances corresponded to what is usually obtained (typically $0.109 \mathrm{~nm}$ for C-H and $0.104 \mathrm{~nm}$ for $\mathrm{N}-\mathrm{H}$ ) and the frequencies calculation was made on this semi-optimized geometry. The resulting IR spectrum, calculated by the B3LYP/6-311++G** method, is plotted on Figure 6 and is very similar to the experimental spectrum allowing a good correlation between the experimental and theoretical data as shown on Figure 7. Thus, the precision is well-sufficient to assign the experimental frequencies and to confirm the attributions proposed above.

\section{Conclusion}

Bis(4-dimethylaminopyridinium) tetrachlorocuprate was synthesized and its structure is reported for the first time in the literature. In the atomic arrangement, the organic layers, built up by the 4-dimethylaminopyridinium cations, are arranged in sandwich between the $\mathrm{CuCl}_{4}^{2-}$ inorganic layers. Intermolecular $\mathrm{N}-\mathrm{H} \cdot \mathrm{Cl}$ and $\mathrm{C}-\mathrm{H} \cdot \mathrm{Cl}$ hydrogen bonds as well as $\pi-\pi$ stacking interactions contribute to the structure cohesion. The vibrational absorption bands were identified by infrared spectroscopy and DFT calculations allowed their attributions.

\section{Supplementary Data}

Crystallographic data for the structural analysis have been deposited with the Cambridge Crystallographic Data Centre, CCDC No 1047063. These data can be obtained free of charge via

http://www.ccdc.cam.ac.uk/conts/retrieving.html, or from the CCDC, 12 Union Road, Cambridge, CB2 1EZ, UK: fax: (+44) 01223-336-033; e-mail: deposit@ccdc.cam.ac.

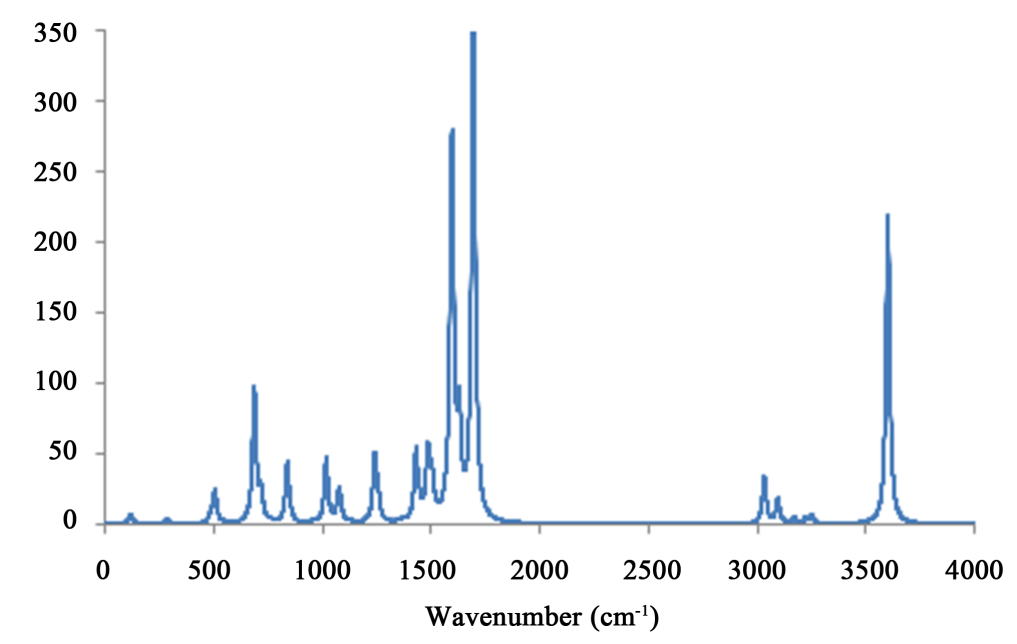

Figure 6. Calculated IR absorption spectrum of $\left(\mathrm{C}_{7} \mathrm{H}_{11} \mathrm{~N}_{2}\right)_{2} \mathrm{CuCl}_{4}$ salt.

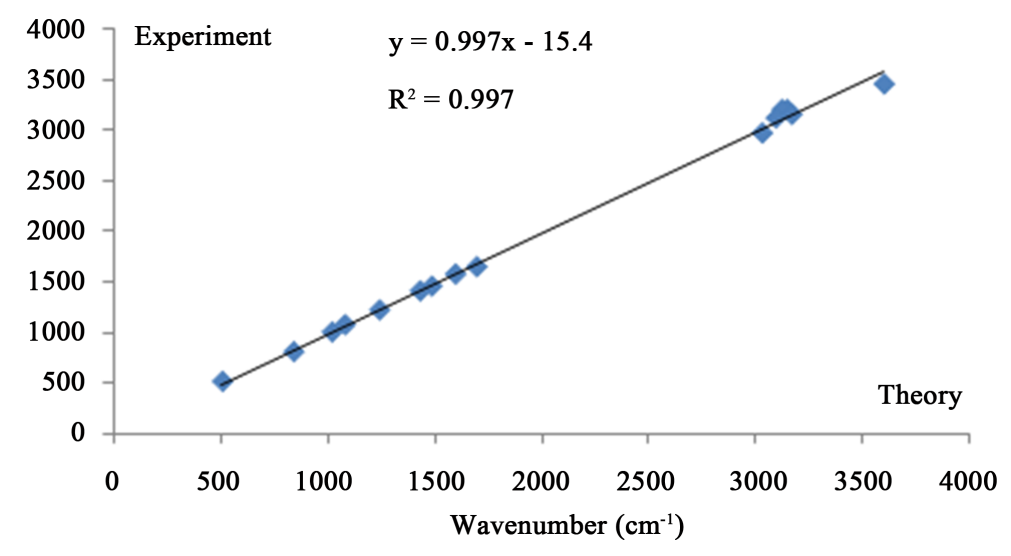

Figure 7. Comparison between experimental and calculated IR frequencies of $\left(\mathrm{C}_{7} \mathrm{H}_{11} \mathrm{~N}_{2}\right)_{2} \mathrm{CuCl}_{4}$ salt. 


\section{Acknowledgements}

We would like to acknowledge the support provided by the Secretary of State for Scientific Research and Technology of Tunisia. The X-ray diffractometer was funded by NSF Grant 0087210, Ohio Board of Regents Grant CAP-491, and by Youngstown State University of USA. A special thank you is needed for Dr. Matthias Zeller, who has helped in collecting and processing X-ray crystallography data.

\section{References}

[1] Desiraju, G.R. (1997) Designer Crystals: Intermolecular Interactions, Network Structures and Supramolecular Synthons. Chemical Communications, 16, 1475-1482. http://dx.doi.org/10.1039/a607149j

[2] Panunto, T.W., Urbanczyk-Lipkowska, Z., Johnson, R. and Etter, M.C. (1987) Hydrogen-Bond Formation in Nitroanilines: The First Step in Designing Acentric Materials. Journal of American Chemical Society, 109, 7786-7797. http://dx.doi.org/10.1021/ja00259a030

[3] Robinson, J.M.A., Philp, D., Harris, K.D.M. and Kariuki, B.M. (2000) Weak Interactions in Crystal Engineering-Understanding the Recognition Properties of the Nitro Group. New Journal of Chemistry, 24, 799-806. http://dx.doi.org/10.1039/b004086j

[4] Hunter, C.A. (1994) Meldola Lecture. The Role of Aromatic Interactions in Molecular Recognition. Chemical Society Reviews, 23, 101. http://dx.doi.org/10.1039/cs9942300101

[5] Desiraju, G.R. and Steiner, T. (1999) The Weak Hydrogen Bond: In Structural Chemistry and Biology. Oxford University Press, Oxford.

[6] Allen, F.H., Hoy, V.J., Howard, J.A.K., Thalladi, V.R., Desiraju, G.R., Wilson, C.C. and McIntyre, G.J. (1997) Crystal Engineering and Correspondence between Molecular and Crystal Structures. Are 2- and 3-Aminophenols Anomalous? Journal of American Chemical Society, 119, 3477-3480. http://dx.doi.org/10.1021/ja964254p

[7] Dolling, B., Gillon, A.L., Orpen, A.G., Starbuck, J. and Wang, X.-M. (2001) Homologous Families of Chloride-Rich 4,4'-Bipyridinium Salt Structures. Chemical Communications, 6, 567-568. http://dx.doi.org/10.1039/b009467f

[8] Mitzi, D.B. and Brock, P. (2001) Structure and Optical Properties of Several Organic-Inorganic Hybrids Containing Corner-Sharing Chains of Bismuth Iodide Octahedra. Inorganic Chemistry, 40, 2096-2104. http://dx.doi.org/10.1021/ic000622l

[9] Luque, A., Sertucha, J., Castillo, O. and Román, P. (2001) Crystal Packing and Physical Properties of Pyridinium Tetrabromocuprate(II) Complexes Assembled via Hydrogen Bonds and Aromatic Stacking Interactions. New Journal of Chemistry, 25, 1208-1214. http://dx.doi.org/10.1039/b104085p

[10] Luque, A., Sertucha, J., Lezama, L., Rojo, T. and Román, P. (1997) Synthesis, Characterisation and Crystal Structure of 2-Aminopyridinium (2-Amino-5-bromopyridine)tribromocuprate(II) and Bis(2-aminopyridinium) Tetrabromocuprate(II). Journal of Chemical Society, Dalton Transactions, 5, 847-854. http://dx.doi.org/10.1039/a606429i

[11] Lewis, G.R. (1998) A Metal-Containing Synthon for Crystal Engineering: Synthesis of the Hydrogen Bond Ribbon Polymer [4,4'- $\mathrm{H}_{2}$ bipy][$\left[\mathrm{MCl}_{4}\right](\mathrm{M}=\mathrm{Pd}, \mathrm{Pt})$. Chemical Communications, 17, 1873-1874. http://dx.doi.org/10.1039/a804128h

Gillon, A.L., Orpen, A.G., Starbuck, J., Wang, X.M., Rodriguez-Martin, Y. and Ruiz-Perez, C. (1999) Cation- Controlled Formation of $\left[\left\{\mathrm{MCl}_{4}\right\}_{n}\right]^{2 \mathrm{n}-}$ Chains in $\left[4,4^{\prime}-\mathrm{H}_{2}\right.$ bipy $]\left[\mathrm{MCl}_{4}\right]\left(\mathrm{M}=\mathrm{Mn}\right.$, Cd): An Alternative to the $\mathrm{A}_{2} \mathrm{MCl}_{4}<100>$ Layer Perovskite Structure. Chemical Communications, 22, 2287-2288. http://dx.doi.org/10.1039/a907681f

Gillon, A.L., Lewis, G.R., Orpen, A.G., Rotter, S., Starbuck, J., Wang, X.M., Rodríguez-Martín, Y. and Ruiz-Pérez, C. (2000) Organic-Inorganic Hybrid Solids: Control of Perhalometallate Solid State Structures. Journal of the Chemical Society, Dalton Transactions, 11, 3897-3905. http://dx.doi.org/10.1039/b005036i

[12] Aakeröy, C.B., Beatty, A.M., Leinen, D.S. and Lorimer, K.R. (2000) Deliberate Combination of Coordination Polymers and Hydrogen Bonds in a Supramolecular Design Strategy for Inorganic/Organic Hybrid Networks. Chemical Communications, 11, 935-936. http://dx.doi.org/10.1039/b0010010

[13] Willett, R.D., Haddad, S.F. and Twamley, B. (2000) Bis(2,6-diamino-3,5-dibromopyridinium) Tetrabromocuprate(II). Acta Crystallographica Section C, 56, e437. http://dx.doi.org/10.1107/S0108270100012105

[14] Willett, R., Place, H. and Middleton, M. (1988) Crystal Structures of Three New Copper(II) Halide Layered Perovskites: Structural, Crystallographic, and Magnetic Correlations. Journal of the American Chemical Society, 110, 86398650. http://dx.doi.org/10.1021/ja00234a010

[15] Severns, J.C., Bunting, R.K. and West, D.X. (1986) Spectral and Thermal Studies of Tetrachlorocobaltate(II) Salts of Aminopyridinium Cations. Inorganica Chimica Acta, 115, L3-L5. http://dx.doi.org/10.1016/S0020-1693(00)87682-3

[16] Prince, B.J., Turnbull, M.M. and Willett, R.D. (2003) Copper(II) Halide Complexes of 2-Aminopyrimidines: Crystal Structures of [(2-Aminopyrimidine $\left.)_{n} \mathrm{CuCl}_{2}\right](n=1,2)$ and (2-Amino-5-bromopyrimidine $)_{2} \mathrm{CuBr}_{2}$. Journal of Coordina- 
tion Chemistry, 56, 441-452. http://dx.doi.org/10.1080/0095897031000099983

[17] Bossert, F., Meyer, H. and Wehinger, E. (1981) 4-Aryldihydropyridines, a New Class of Highly Active Calcium Antagonists. Angewandte Chemie International Edition in English, 20, 762-769. http://dx.doi.org/10.1002/anie.198107621

[18] Lohaus, G. and Dittmar, W. (1968) S. Afr. Patent 6906036.

[19] Wang, S.D., Herbette, L.G. and Rhodes, D.G. (1989) Structure of the Calcium Channel Antagonist, Nimodipine. Acta Crystallographica Section C, 45, 1748-1751. http://dx.doi.org/10.1107/S010827018900329X

[20] Al-Far, R.H. and Ali, B.F. (2008) The Crystal Structures of Bis(2-amino-5-methylpyridinium) Tetrabromometallate(II): Intermolecular Interactions in $\left(\mathrm{C}_{6} \mathrm{H}_{9} \mathrm{~N}_{2}\right)_{2}\left[\mathrm{MBr}_{4}\right] ; \mathrm{M}=\mathrm{Cd}$ and Co. Journal of Chemical Crystallography, 38, 373-379. http://dx.doi.org/10.1007/s10870-007-9304-8

[21] Al-Far, R. and Ali, B.F. (2007) Noncovalent Supramolecular Interactions in the Crystal Structure of 2-Amino-3,5-dibromo-4,6-dimethylpyridinium Tetrabromocadmate(II). Journal of Chemical Crystallography, 37, 333-341. http://dx.doi.org/10.1007/s10870-006-9161-x

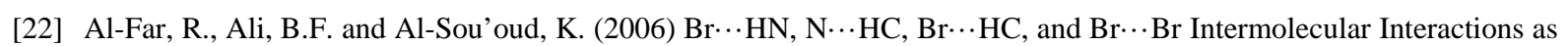
Supramolecular Synthons: Synthesis and Crystal Structure of Bis(2-amino-5-methylpyridinium) Tetrabromomercurate(II). Journal of Chemical Crystallography, 36, 523-529. http://dx.doi.org/10.1007/s10870-006-9080-x

[23] Ali, B.F., Al-Far, R. and Haddad, S.F. (2010) Hydrogen Bonded, $\pi \cdots \pi$ Stacked and X $\cdots \pi$ Framework Structures in Bis(2,6-Lutidinium) Tetrahalocuprate(II) Complexes. Journal of Chemical Crystallography, 40, 696-701. http://dx.doi.org/10.1007/s10870-010-9724-8

[24] Bruker AXS Inc. Apex2 v2011.2-0, Bruker Advanced X-Ray Solutions. Bruker AXS Inc., Madison.

[25] Sheldrick, G.M. (2008) A Short History of SHELX. Acta Crystallographica Section A, 64, 112-122. http://dx.doi.org/10.1107/S0108767307043930

[26] Bruker AXS Inc. (2003) Bruker Advanced X-Ray Solutions, SHELXTL (Version 6.14). Bruker AXS Inc., Madison.

[27] Hübschle, C.B., Sheldrick, G.M. and Dittrich, B. (2011) ShelXle: A Qt Graphical User Interface for SHELXL. Journal of Applied Crystallography, 44, 1281-1284. http://dx.doi.org/10.1107/S0021889811043202

[28] Macrae, C.F., Edgington, P.R., McCabe, P., Pidcock, E., Shields, G.P., Taylor, R., Towler, M. and van de Streek, J. (2006) Mercury: Visualization and Analysis of Crystal Structures. Journal of Applied Crystallography, 39, 453-457. http://dx.doi.org/10.1107/S002188980600731X

[29] Halvorson, K.E., Patterson, C. and Willett, R.D. (1990) Structures of Bis(4-aminopyridinium) Tetrachlorocuprate(II) Monohydrate, $\left[\mathrm{C}_{5} \mathrm{H}_{7} \mathrm{~N}_{2}\right]_{2}\left[\mathrm{CuCl}_{4}\right] \cdot \mathrm{H}_{2} \mathrm{O}$ and Bis(2-amino-3-hydroxypyridinium) Tetrachlorocuprate(II), $\left[\mathrm{C}_{5} \mathrm{H}_{7} \mathrm{~N}_{2} \mathrm{O}\right]_{2}[\mathrm{CuCl} 4]$ : Correlation of $\mathrm{CuCl}_{4}^{2-}$ Geometry with Hydrogen Bonding and Electronic Structure. Acta Crystallographica Section B, 46, 508-519. http://dx.doi.org/10.1107/S010876819000338X

[30] Kefi, R., Lefebvre, F., Matthias, Z. and Ben Nasr, C. (2010) Bis[4-(dimethylamino)pyridinium] Tetrachloridozincate. Acta Crystallographica Section E, 67, m343. http://dx.doi.org/10.1107/S1600536811005010

[31] Thomas, S.P. and Sunkari, J. (2013) 2-Amino-4-methylpyrimidinium Dihydrogen Phosphate. Acta Crystallographica Section E, 69, o529. http://dx.doi.org/10.1107/S160053681300648X

[32] Jin, Z.M., Pan, Y.J., Xu, D.J. and Xu, Y.Z. (2000) The 1:1 Complex of 4-Nitrophenol and 4-Methylpyridine. Acta Crystallographica Section C, 56, e69-e70. http://dx.doi.org/10.1107/S0108270100001074

[33] Boenigk, D. and Mootz, D. (1988) Fluorides and Fluoro Acids. Part 18. The System Pyridine-Hydrogen Fluoride at Low Temperatures. Formation and Crystal Structures of Solid Complexes with Very Strong NHF and FHF Hydrogen Bonding. Journal of the American Chemical Society, 110, 2135-2139. http://dx.doi.org/10.1021/ja00215a021

[34] Vembu, N., Nallu, M., Garrison, J. and Youngs, W.J. (2003) 4-Dimethylaminopyridinium Picrate: Supramolecular Aggregation through Extensive N-H...O and C-H...O Interactions. Acta Crystallographica Section E, 59, o913-o916. http://dx.doi.org/10.1107/S1600536803012212

[35] Nassimbeni, L.R., Rodgers, A.L. and Haigh, J.M. (1976) The Crystal and Molecular Structure of the Bis(4-N,N'-dimethylaminopyridine) Solvate of di- $\mu$-salicylicacidato Bis\{nitratodioxouranium(VI)\}. Inorganica Chimica Acta, 20, 149-153. http://dx.doi.org/10.1016/S0020-1693(00)94108-2

[36] Vembu, N., Nallu, M., Spencer, E.C. and Howard, J.A.K. (2003) 4-Dimethylaminopyridinium 2,4-Dinitrophenolate: Supramolecular Aggregation through $\mathrm{N}-\mathrm{H} . . . \mathrm{O}, \mathrm{C}-\mathrm{H} . . . \mathrm{O}, \mathrm{C}-\mathrm{H} . . . \pi$ and $\pi-\pi$ Interactions. Acta Crystallographica Section E, 59, o1383-01386. http://dx.doi.org/10.1107/S1600536803018178

[37] Brzozowski, Z., Sạczewski, F. and Gdaniec, M. (2003) Synthesis, Structural Characterization and in Vitro Antitumor Activity of Novel 6-Chloro-1,1-dioxo-1,4,2-benzodithiazie Derivatives. Bioorganic \& Medicinal Chemistry, 11, 36733681. http://dx.doi.org/10.1016/S0968-0896(03)00345-6 
[38] Garino, C., Gobetto, R., Nervi, C., Salassa, L., Croce, G., Milanesio, M., Rosenberg, E. and Ross, J.B.A. (2005) Solid-State Structure, Quantum Calculations and Spectroscopic Characterization of the Hydrogen-Bonded Complex $\left[\mathrm{Os}(\mathrm{bpy})_{2}(\mathrm{CO})(\mathrm{EtO} . . . \mathrm{H}-\mathrm{DMAP})\right]\left[\mathrm{PF}_{6}\right]_{2}$. European Journal of Inorganic Chemistry, 2005, 606-614. http://dx.doi.org/10.1002/ejic.200400631

[39] Mayr-Stein, R. and Bolte, M. (2000) 4-Dimethylaminopyridinium Bromide. Acta Crystallographica Section C, 56, e19-e20. http://dx.doi.org/10.1107/S0108270199016133

[40] Sluka, R., Nečas, M. and Černík, M. (2003) Bis(4-dimethylaminopyridinium) 1,2-Difluorodiphosphate. Acta Crystallographica Section E, 59, o190-o192. http://dx.doi.org/10.1107/S1600536803001004

[41] Bryant Jnr, G.L. and King Jnr, J.A. (1992) Structures of Two Acylpyridinium Salts and One Simple Pyridinium Salt. Acta Crystallographica Section C, 48, 2036-2039. http://dx.doi.org/10.1107/S0108270192002403

[42] Hosomi, H., Ohba, S. and Ito, Y. (2000) Charge-Transfer Complexes of 4-(Dimethylamino)pyridine with 2,4-, 3,4- and 3,5-dinitrobenzoic Acid. Acta Crystallographica Section C, 56, e149-e150. http://dx.doi.org/10.1107/S0108768100003864

[43] Dega-Szafran, Z., Gdaniec, M., Grundwald-Wyspianska, M., Kosturkiewicz, Z., Koput, J., Krzyzanowski, P. and Szafran, M. (1992) X-Ray, FT-IR and PM3 Studies of Hydrogen Bonds in Complexes of Some Pyridines with Trifluoroacetic Acid. Journal of Molecular Structure, 270, 99-124. http://dx.doi.org/10.1016/0022-2860(92)85022-9

[44] Porcs-Makkay, M., Argay, G., Kálmán, A. and Simig, G. (2000) Synthesis of 1,3-Di[alkoxy(aryloxy)carbonyl]-2-oxo2,3-dihydroindoles. Tetrahedron, 56, 5893-5903. http://dx.doi.org/10.1016/S0040-4020(00)00477-4

[45] Porcs-Makkay, M. and Simig, G. (2000) New Practical Synthesis of Tenidap. Organic Process Research \& Development, 4, 10-16. http://dx.doi.org/10.1021/op990067a

[46] Huang, K.S., Britton, D., Etter, M.C. and Byrn, S.R. (1997) A Novel Class of Phenol-Pyridine Co-Crystals for Second Harmonic Generation. Journal of Materials Chemistry, 7, 713-720. http://dx.doi.org/10.1039/a604311j

[47] Le Fur, Y., Pécaut, J. and Levy, J.P. (1993) Crystal Structure of Bis(4-methoxypyridine-N-oxide)dichlorocopper, $\left(\mathrm{C}_{6} \mathrm{NO}_{2} \mathrm{H}_{7}\right)_{2}\left(\mathrm{CuCl}_{2}\right)$. Zeitschrift für Kristallographie-Crystalline Materials, 208, 255-256. http://dx.doi.org/10.1524/zkri.1993.208.Part-2.255

[48] Haddad, S. and Willett, R.D. (2001) Crystal Structure of Bis(4-dimethylaminopyridinium) Tribromocuprate(I) and Bis(4-dimethylaminopyridinium) Tetrabromocuprate(II). Journal of Chemical Crystallography, 31, 37-43. http://dx.doi.org/10.1023/A:1013726618985

[49] Majerz, I., Malarski, Z. and Lis, T. (1989) Structure and IR Spectroscopic Behaviour of the 4-Dimethylaminopyridinium Pentachlorophenolate Hemihydrate. Bulletin of the Polish Academy of Sciences-Chemistry, 37, 81-89.

[50] Haddad, S. and Willett, R.D. (2001) Polymorphism in Bis(4-dimethylamino-pyridinium)tetrachlorocuprate(II). Inorganic Chemistry, 40, 2457-2460. http://dx.doi.org/10.1021/ic000613c

[51] Yano, S., Kato, M., Tsukahara, K., Sato, M., Shibahara, T., Lee, K., Sugihara, Y., Iida, M. and Goto, K. (1994) Chemical Modification of Metal Complexes. An Efficient Procedure for O-Acylation of an Anionic Metal Complex Having a Noncoordinated Hydroxyl Group. Inorganic Chemistry, 33, 5030-5035. http://dx.doi.org/10.1021/ic00100a030

[52] Majerz, I., Malarski, Z. and Sawka-Dobrowolska, W. (1995) Structure and IR Spectroscopic Properties of the Anhydrous 4-N,N-dimethylaminopyridinium Pentachlorophenolate. Journal of Chemical Crystallography, 25, 189-193. http://dx.doi.org/10.1007/BF01666105

[53] Janiak, C. (2000) A Critical Account on $\pi-\pi$ Stacking in Metal Complexes with Aromatic Nitrogen-Containing Ligands. Journal of the Chemical Society, Dalton Transactions, 21, 3885-3896. http://dx.doi.org/10.1039/b003010o

[54] Koleva, B.B., Kolev, T., Seidel, R.W., Tsanev, T., Mayer-Figge, H., Spiteller, M. and Sheldrick, W.S. (2008) Spectroscopic and Structural Elucidation of 4-Dimethylaminopyridine and Its Hydrogensquarate. Spectrochimica Acta Part A: Molecular and Biomolecular Spectroscopy, 71, 695-702. http://dx.doi.org/10.1016/j.saa.2008.01.033

[55] Hu, Y.L., Lin, J.H., Han, S., Chen, W.Q., Yu, L.L., Zhou, D.D., Yin, W.T., Zuo, H.R., Zhou, J.R., Yang, L.M. and Ni, C.L. (2012) Syntheses, Crystal Structures and Properties of Two New Ion-Pair Complexes by Self-Assembly of Bis(maleonitriledithiolate)copper(II)/nickel(III) Anion and Substituted 4-Dimetylaminopyridinium. Synthetic Metals, 162, 1024-1029. http://dx.doi.org/10.1016/j.synthmet.2012.04.011 